\title{
Democracy finally wins
}

\section{Moscow}

ON 20 April, the Soviet Academy of Sciences finally elected its quota of deputies to the country's new parliament, bringing to an end the four-month election campaign to the Congress of People's Deputies that will form the Soviet parliament.

Members of the Soviet Academy had wanted to be represented by socially orientated legislators, people with radical reform programmes in their pockets, who would firmly and boldly struggle against the administrative and command system, rather than talking about perestroika.

The election procedure in this public organization has evoked much interest both in the Soviet Union and abroad. In March, the academy's election conference annulled the decision of the extended plenum of the academy's leadership, held last January, to nominate 23 candidates for 20 vacancies and to ignore a long list of names advanced by numerous academic institutes. Then, only eight candidates won the necessary number of votes (at least one more than the number entitled to vote), while the other 12 seats remained vacant. This triggered the legal requirement for the follow-up elections.

The academy's leadership learned the lesson. They took into account proposals advanced by academic institutes, invited the press and the pressure group called "For Democratic Elections in the Soviet Academy". Voting by a show of hands, they nominated 25 candidates for 12 seats. (On the last day before the vote, the wellknown Soviet economist, Academician

\section{NUCLEAR REACTORS \\ Superphénix go-ahead}

\section{Paris}

Superphénix, the French fast-breeder reactor, has been given the go-ahead to begin generating electricity again after a twoyear interruption while a structural fault was investigated. Earlier this year, the reactor was restarted without its leaky fuelrod transit chamber, despite protests from environmental groups in neighbouring Switzerland who want the plant to be closed down.

Following trials without producing electricity, the French nuclear safety authorities are satisfied that the generator can resume full-power output $(1,200 \mathrm{MW})$ within the next two months. But environmental groups are outraged that no independent inquiry has been carried out and say that to restart the generator without the transit chamber will leave the plant with no safe site to allow fuel rods to cool in the event of an accident. A new transit system for fuel rods is being installed and will be ready for the autumn.

Peter Coles
Stanislav Shatalin, withdrew from the elections for health reasons.)

The election conference was attended by 1,101 voters, including Soviet academicians, non-voting members of the academy and 433 representatives of academic institutes. The voting was preceded by heated debates: all candidates presented their political, social and legal programmes and answered scores of tough questions about the most pressing issues of perestroika.

The support of grass-roots organizations proved decisive. Those elected were, among academicians, Andrei Sakharov, Roald Sagdeev, Vitaly Ginzburg and Georgy Arbatov and, among non-voting members of the academy, Sergei Averintsev, Pavel Bunich and Nikolai Petrakov. Other successful candidates were doctors of economics Nikolai Shmelev and Gennadi Lisichkin, both well-known authors of strongly worded articles; Dr Alexander Yakovlev, a lawyer; Yuri Kariakin, head research worker of the Institute of the International Labour Movement; and $\mathrm{Dr}$ Viacheslav Ivanov, a philologist.

On balance, the Soviet Academy of Sciences has passed its examination in democracy with flying colours. Undoubtedly, its deputies to the Soviet Parliament as well as scientists elected from other public organizations, territorial and national-territorial districts, will represent a powerful group working to speed up the radical restructuring of domestic and foreign policies.

Yuri Kanin

\section{AIDS}

\section{Controversial visa ban}

\section{Washington}

The US policy of denying entry visas to foreigners infected with the human immunodeficiency virus, the virus which causes AIDS, may become a contentious issue before next year's international AIDS conference, scheduled to take place in San Francisco, California. Several researchers are expected to introduce a resolution at this year's conference in Montreal, Canada to move the 1990 conference to a country that does not screen travellers for HIV infection.

The United States passed a law two years ago prohibiting immigrants and aliens infected with HIV from routinely entering the country. Several US congressmen have said that the intent of the law was to turn away HIV-infected immigrants seeking permanent residence, but the law recently was invoked to detain a Dutch city official with AIDS who was travelling to the United States for a health conference.

Carol Ezzell

\section{Test flight of IRBM abandoned after}

\section{postponements}

\section{New Delhi}

INDIA's eagerly awaited test flight of its first intermediate-range ballistic missile (IRBM) did not take place on 20 April as scheduled, disappointing dignitaries including the defence minister and the three service chiefs who had come to witness the launch from Chandipur in coastal Orissa state. The launch time was postponed three times and late in the afternoon the Defence Research Development Organisation (DRDO), which developed the missile, announced that the test had been put off indefinitely. No reasons were given, although unofficial reports said the mission was aborted because of technical problems.

The two-stage, 100-tonne missile named Agni is said to have a range of $2,500 \mathrm{~km}$ and to be able to deliver a warhead weighing more than a tonne. Except for the inertial navigation system, for which France provided help, the missile is claimed to be fully indigenous. The first stage is solidfuelled for quick acceleration and the second is propelled by a storable liquid of very high specific impulse.

Although not officially stated, the main aim of the launch was to evaluate the performance of the heat shield - an important piece of hardware in a weapon delivery system - during its re-entry through the atmosphere.

The missile, in fact, had been named after this important mission objective (agni means fire in Sanskrit). Although DRDO had developed the heat shield some time ago, its testing had to wait until Agni was ready.

After Trishul and Prithvi, Agni is the third missile to roll out of the DRDO laboratories in Hyderabad. Trishul is a short-range (12-km) surface-to-surface missile.

The postponement of the IRBM launch after much publicity is a setback to DRDO which had hoped to score over Pakistan's recent success with its HATF-2 missile, which brings Bombay and Delhi within range. Prithvi, DRDO's long-range surface-to-surface missile, has a range of just $250 \mathrm{~km}$. It has yet to enter the production phase.

DRDO would have launched Agni secretly had there been no population near the test range. As it turned out, opposition by some 12,000 villagers to mass evacuation from their homes in the safety zone brought the event under the glare of national and international publicity. Meanwhile, DRDO has not given any indication of when it will fire Agni next.

K.S. Jayaraman 